\title{
Study on Seasonal Variation on the Content of Cucurbitacin of Various Vegetative Parts of Trichosanthes cucumerina L. var. cucumerina
}

\author{
N. K. Devendra ${ }^{1^{*}}$, E. G. Attard ${ }^{2}$, D. Raghunandan ${ }^{3}$, Y. N. Seetharam ${ }^{1}$ \\ ${ }^{1}$ Plant systematics and Medicinal Plant Laboratory Department of P.G. Studies and research in Botany Gulbarga University, GULBAR- \\ GA-585 106, India \\ ${ }^{2}$ Institute of Agriculture, University of Malta, Msida MSD-06, Malta \\ ${ }^{3}$ H.K.E.S's Matoshree Taradevi Rampure Institute of Pharmaceutical Sciences, Sedam Road, GULBARGA - 585105, Karnataka, India
}

\begin{abstract}
The total cucurbitacin content produced in the different parts of T. cucumerina L. var. cucumerina viz., fruit, stem and leaves with time and temperature was studied during the year 2007-08. The highest amount of cucurbitacins was produced in the month of February, i.e., $0.8,1.7$ and $3.7 \mathrm{w} / \mathrm{w} \%$ and lowest was in the month of July $1.9,0.5$ and $0.17 \mathrm{w} / \mathrm{w} \%$ in fruit, stem and leaves respectively. Present study reviles that, Production of cucurbitacin is temperature dependent as the temperature increases cucurbitacins production increased; decrease in the temperature production of cucurbitacins was found decrease. Due to high content of cucurbitacins, this plant may prove itself as a potent hepatoprotective, anti-inflammatory, cytotoxic agent, antifeedant and antimicrobial properties of the plants.
\end{abstract}

Keywords Trichosanthes cucumerina L. var. cucumerina, Seed Dormancy, Seed Germination, Cucurbitacins

\section{Introduction}

Cucurbitacin are the rich oxygen containing compounds of the genera cucurbitaceous for example Citrullus, Cucurbita luffa and Cucumis[1]. Cucurbitacin E is cucurbitaceous species offer high concentration of cucurbitacin. Cucurbitaceous exhibits positive effects both pharmacologically[2-6] and act as immune developing agents in plants to fight against certain diseases[7,8]. They are also known to possess severe bitterness even at a concentration lower than 10 $\mathrm{ppb}$ [9], with the emergence of new cultivar to determine the efficiency of a technique that identifies these cucurbitacins in plant tissue. We have carefully chosen Trichosanthes cucumerina $\mathrm{L}$. var. cucumerina that stores an abundance of these compounds.

T. cucumerina L. var. cucumerina is Ayurvedic medicinal plant belongs to family Cucurbitaceae. More than 16 herbal products are available in the market in which T. cucumerina L. var. cucumerina is one of the important ingredients[10]. The plant is effectively used in various indications, whole plant extract as depurative stomachic in nineteenth century Cayenne, French Guiana[11], to reduce congestion on congestive cardiac failure[12] aphrodisiac[13]. Leaf as intermittent fever[14], skin disease[15], bald patches of

\footnotetext{
* Corresponding author:

microraghu@yahoo.co.in ( N. K. Devendra )

Published online at http://journal.sapub.org/plant

Copyright (C) 2011 Scientific \& Academic Publishing. All Rights Reserved
}

alopecia[16].

Fruit is regarded as anthelmintic, vomitive[17] antidiabetic[18] for boil[19]. Seeds anthelmintic,and anti fibrile[20]. Root is used as purgative and tonic.

The pharmacological activities of cucurbitacin containing plants have been known since ancient times. Cucurbitacins are particularly known in folk medicine for their strong purgative, anti-inflammatory, and hepatoprotective activities[1]. Moreover, the natural cucurbitacins constitutes a group of triterpenoids substances which are well known for their bitterness and toxicity[21]. And there have been instance of severe poisoning and death in sheep and cattle that consumed bitter fruits from cucumis and cucurbita[22]. Bitter zucchini containing 50-600 ppm cucurbitacins has toxic effects in humans with dose of three grams[23]. It has therefore been important to determine the content of free cucurbitacins in herbal remedies.

\section{Material Methods}

Trichosanthes cucumerina L. var. cucumerina seeds were obtained from mature fruits collected from Khanapur forest Bhalki taluka, Bidar District (Karnataka state) India, in the month of June-2006. The seeds were $(\mathrm{n}=100)$ washed with running tap water followed by distilled water than dried, decoated and soaked for $24 \mathrm{hrs}$ in a beaker with distilled water. The treated seeds were placed in trays and allowed for several weeks to germinate. The germinated seedlings were 
placed in a pot and kept in a growth chamber at $24^{\circ} \mathrm{C}$ and relative humidity of about $90 \pm 5 \%$. Plants were routinely watered twice daily. When an apical height of $20 \mathrm{~cm}$ was reached, the plants were planted in soil. They were allowed to grow for one year from June 2007- February 2008.

\subsection{Determination of Cucurbitacins}

At monthly interval two plants were sacrificed and the fruits, stem and leaves were gathered. The juice was extracted from each plant part by homogenization and filtration. In case of stems and leaves distilled water was added to aid the extraction of the juice. The juice obtained was dried in an oven at $40^{\circ} \mathrm{C}$, to obtain the dried cucurbitacin; the cucurb itacin content was determined using cucurbitacin $\mathrm{E}$ as the reference for the total cucurbitacin content.

\subsection{Solvents and Reagents}

Absolute ethanol, petroleum ether $30-40^{\circ} \mathrm{C}$, chloroform and phosphomolybdic acid. A cucurbitacin $\mathrm{E}$ reference standard was obtained from Prof. Everaldo G. Attard, Institute of Agriculture, University of Malta, Msida, MSD06, Malta.

\subsection{Sample Solutions}

For total cucurbitacin assay, shade dried various vegetative parts of the plant material (100-200 mg per sample) was extracted with absolute ethanol $(5 \mathrm{ml})$ for $2 \mathrm{~h}$, after centrifugation (2000 rpm for $3 \mathrm{~min}$ ), the supernatant was mixed with an equal volume of petroleum ether, the precipitate obtained was filtered and dissolved in absolute ethanol $(5 \mathrm{ml})$, and then reduced to a volume of $2 \mathrm{ml}$.

\subsection{Reference Solution}

The reference standard cucurbitacin $\mathrm{E}$ was dissolved in ethanol and serial dilutions $(0.01-1.0 \mathrm{mg} / \mathrm{ml})$ were prepared.

\section{Assay}

All samples $(100 \mu 1$, in duplicate), together with various concentrations of cucurbitacin E standard, were mixed with $100 \mu \mathrm{l}$ of a solution of phosphomolybdic acid in absolute ethanol[24] at room temperature. The absorbance was measured at $492 \mathrm{~nm}$ after $5 \mathrm{~min}$ on a MTP reader STATFAX2100, USA. The results were expressed as $\mathrm{w} / \mathrm{w} \%$ calculated from dry callus weight and then analyzed statistically by ANOVA.

\section{Results and Discussion}

\subsection{Cultivation Studies}

Although dormancy is the main problem with the seed this was overcome by treating seeds at $45^{\circ} \mathrm{C}$ in tray d ryers [25] and then decoated seeds were immersed in water overnight. It was noticed that germination was two staged, (Figure-1) with $40 \%$ of the seed germinating within the first 20-days. There was an average of two seeds per day and 3.5 seeds per day for the following 15-days. The highest percentage of seed germination was $89 \%$. The germinated plantlets after attaining $20-25 \mathrm{cms}$ in the pot then transferred to field condition. Figure 1 shows the different parts of cucumerina L. var. cucumerina.

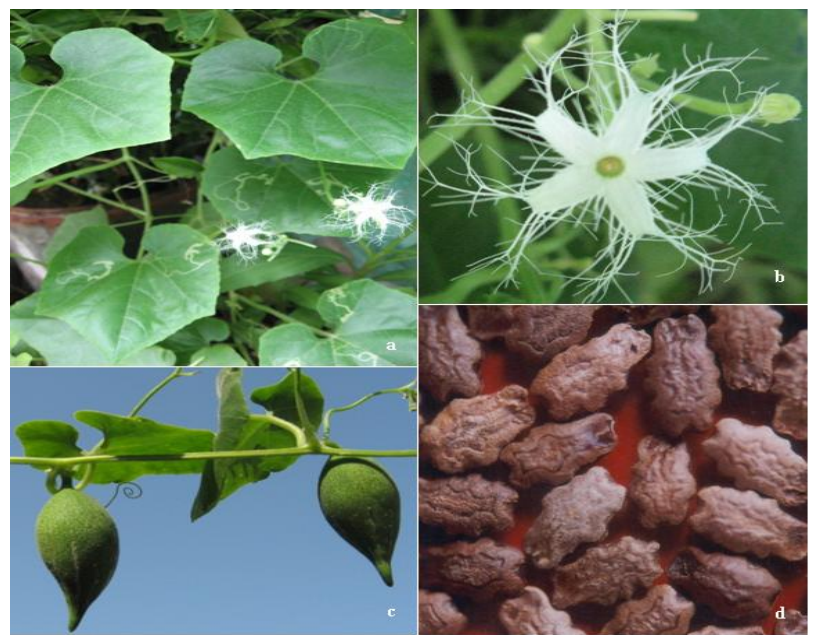

Figure 1. Different parts of. cucumerina L. var. cucumerina. A) leafs b) flower c) fruits d) seeds.

\subsection{Cucurbitacin Survey and Contents}

A survey of the Khanapur Forest, Khanapur, Bidar district, Karnataka was conducted in the month of June - October 2006. The plant material of Trichosanthes cucumerina L. var. cucumerina (Cucurbitaceae) has been collected at the fruiting stage from the forest. The whole plant, fruits and seeds were collected separately in the sterilized polythene bags.

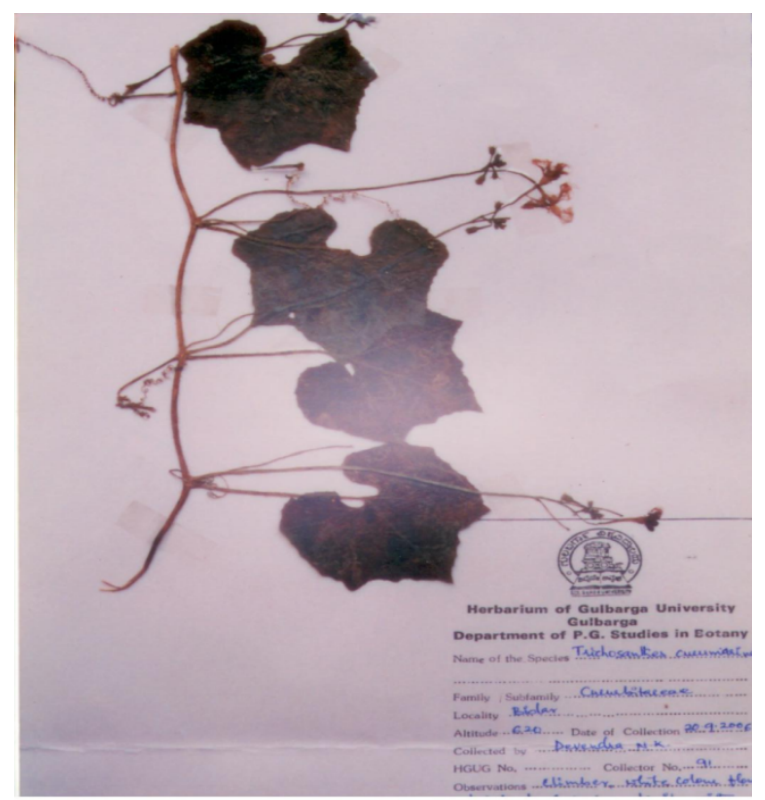

Figure 3. Authentication report for the Trichosanthes cucumerina L. var. cucumerina plant.

Figure 3 gives the details of authentication certificate from botany department of Gulbarga University, Gulbarga. A specimen of the species was deposited in the Herbarium of 
Botany department, Gulbarga University, Gulbarga (Voucher No. HGUG-804). Also, the plant was confirmed with authenticated herbariums at the Centre for Ecological Studies, IISc, B'lore, and Botanical Survey of India, Pune.

Table 1. The total cucurbitacin concentration in T. cucumerina L. var. cuc merina produced from fruit, stem and leaves with time and temperature.

\begin{tabular}{ccccc}
\hline \multirow{2}{*}{ Month } & Fruits & Stem & Leaves & Temp. \\
\cline { 2 - 4 } & $\begin{array}{c}\mathbf{C u} \\
\mathbf{m g} / \mathbf{1 0 0 g}\end{array}$ & $\begin{array}{c}\mathbf{C u} \\
\mathbf{m g} / \mathbf{1 0 0 g}\end{array}$ & $\begin{array}{c}\mathbf{C u} \\
\mathbf{m g} / \mathbf{1 0 0 g}\end{array}$ & \\
\hline June & - & 0.9 & 0.35 & 32.9 \\
July & 1.9 & 0.5 & 0.17 & 30.9 \\
Aug & 1.8 & 0.5 & 0.23 & 29.6 \\
Sept & 2.0 & 0.5 & 0.21 & 31.3 \\
Oct & 2.7 & 1.03 & 0.49 & 33 \\
Nov & 3.5 & 1.04 & 0.56 & 33.2 \\
Dec & 1.7 & 0.6 & 0.25 & 32.5 \\
Jan & 3.7 & 1.6 & 0.7 & 35 \\
Feb & 3.7 & 1.7 & 0.8 & 35 \\
\hline
\end{tabular}

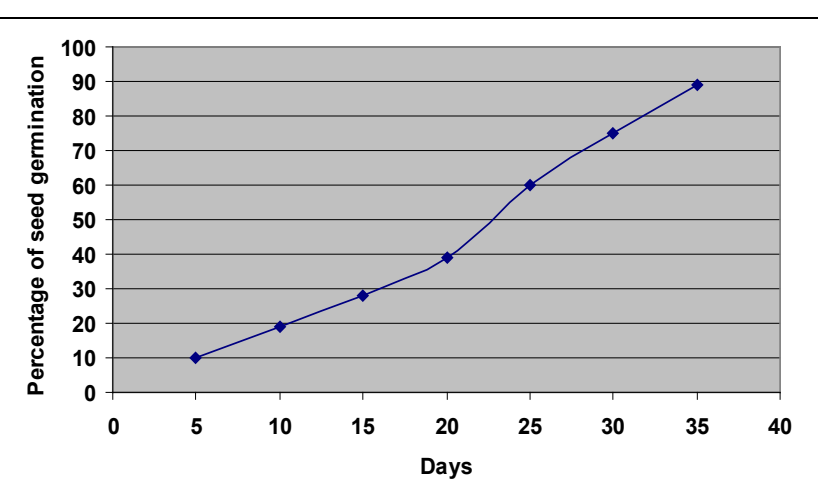

Figure 2. The percentage germination of T. cucumerina L. var. cucumerina with time.

The total cucurbitacin content (Figure-2) in T. cucumerina L. var. cucumerina produced from fruit, stem and leaves was also studied over the 270-days period. The fruit showed the highest mean total cucurbitacin content $(3.5 \mathrm{mg} / 100 \mathrm{~g})$ followed by stem $(1.04 \mathrm{mg} / 100 \mathrm{~g})$ and leaves $(0.56 \mathrm{mg} / 100 \mathrm{~g})$.

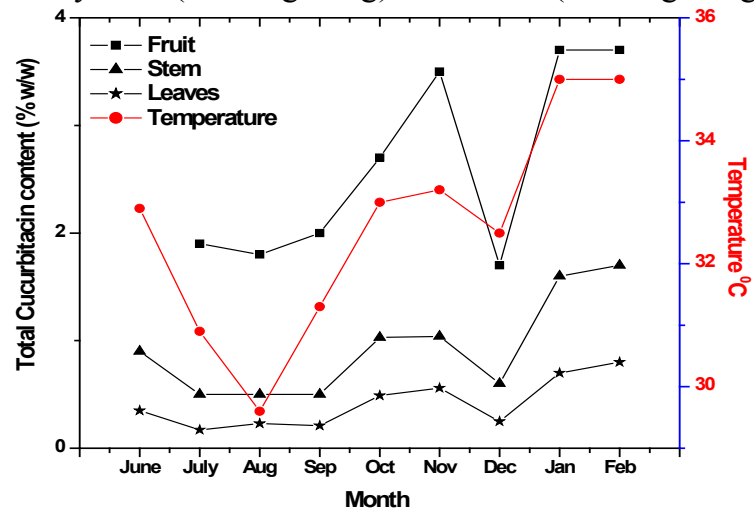

Figure 4. The total cucurbitacin content in T. cucumerina L. var. cuc merina produced from fruit, stem and leaves with time and temperature.
The stems are involved in the transportation of cucurbitacins but only the fruits are associated with storage. Although the leaves contained a low concentration of cucurbitacins or the role cucurbitacins is still important as antifeedants. For example, the bitterness of cucurbitacin $\mathrm{E}$ is experienced at a low concentration of $10 \mathrm{ppb}$ [9] a concentration that is not detectable by quantitative methods used [26] determined cucurbitacin content in the fruit 40 times greater than in the leaves of Ecballium elaterium.[27] determined 22 times greater than that of the leaves. In present study considering the fresh plant material, the cucurbitacin content in the fruit is about 15 times greater than that of the leaves is adequate to promote and conduct various pharmacological activities, as hepatoprotective, anti-inflammatory, cytotoxic agent, antifeedant and antimicrobial [28] properties of the plants. This study reveals that production of cucurbitacins is temperature dependent (Figure-2), increase in temperature increases cucurbitacins and cucurbitacin $\mathrm{E}$ production.

\section{REFERENCES}

[1] Lavie D and Glotter E. The Cucurbitanes; a Group of Tetracyclic Triterpenes; Progress in the Chemistry of Organic Natural Products XXIX; New York; U.S.A. - English Translation; pp. 1971, 352-354

[2] Attard E, Scicluna-Spiteri A, Grixti M. and Cuschieri A. 1996. The Cytotoxic Activity of Cucurbitacin E and Busulphan on Ovarian and Stomach Cancer Cells in vitro: A Comparative Study. Xjenza. 1:29-34

[3] Attard E., Scicluna-Spiteri A, Brincat M, and Cuschieri. A. 1999. The effects of Cucurbitacin $\mathrm{E}$ on the proliferation of prostate and breast cancer cell lines, and peripheral T-lymphocytes. Maltese Fourth Med. School Conf. R034:145

[4] Sturm S and Stuppner H. 2000. Analysis of cucurbitacins in medicinal plants by high- pressure liquid chromatography mass spectrometry. Phytochem Anal 11: 121-127

[5] Jayaprakasam N., Seeram P and Nair M.G. 2003. Purine-containing cucurbitane triterpenoids from Cucurbita pepo cv dayangua. Cancer Lett. 189: 1 1-6

[6] Jiazhi, S Michelle A.B., Richard J, Sandra K.L., Domenico C and Saïd M.S. 2005. Cucurbitacin Q: a selective STAT3 activation inhibitor with potent antitumor activity. Oncogene., 24: $3236-3245$

[7] Bar-Nun N and Mayer A.M., 1990. Cucurbitacins protect cucumber tissue against infection by Botrytis cinerea. Phytochem. 29:787-791

[8] Kaya G.I., and Melzıg M.F., 2008. Quantitative determination of cucurbitacin E and cucurbitacin I in homoeopathic mother tincture of Gratiola officinalis L. by HPLC. Pharmazie. 63 : $851-853$

[9] Kirschman J.C. and Suber R.L., 1989. Recent Food Poisonings from Cucurbitacin in Traditionally Bred Squash. Fd. Chem. Toxic. 27:555-556 
[10] Devendra N.K., Rajanna L, Sheetal C and Seetharam Y.N., 2008. In vitro Clonal Propagtion of Trichosanthes cucumerina L. var. cucumerina. Plant Tissue Cult. \& Biotech. 18(2): 103-111

[11] Heckel, E 1897. Les Plantes Médicinales et Toxiques de la Guyane Francaise. 93 pp. Macon, France: Protat Freres.

[12] Pullaih.T, 2006. Encyclopaedia of World Medicinal Plants. Vol-IV, Regency Publication New Delhi. pp-1977.

[13] Sood, S. K., Sarita, R and Lakhanpal, T. N 2005. Ethnic Aphrodisiac plants.Scientific publishers (India) Jodhpur, pp-118.

[14] Kirtikar and Basu. 2000. Indian Medicinal Plants. Sri Satguru Publications, New Delhi. (5):1545-1547.

[15] Chopra, R. N., Nayar, S. L and Chopra, I. C 1969. Glossary of Indian Medicinal Plants. Counsil of scientific and industrial research, New Delhi, pp-248.

[16] Annonymous. 1976. Welth of India. Vol-10, CSIR, New Delhi, pp-291.

[17] Jeffrey, C (1984). Cucurbitaceae, pp. 457-518. In: Stoffers, A.L. and J.C. Lindeman, eds., Flora of Surinam. Vol. 5, Part 1. Leiden: E.J. Brill.

[18] Devendra N. K., Vijaykumar B. M and Seetharam Y. N. 2010. Folklore Medicinal Plants of Gulbarga District, Karnataka, India. e-Journal of Indian Medicine. 3(1); 23-30.

[19] Srivastava, R. C., Singh, V. P and Singh, M. K. 2003. Medicinal plants of Jaunapur District U. P. India. In Singh et al., (ed.) Ethnobotany and medicinap plants of India and Nepal. Vol-I, Scientific publishers (India).
[20] Nadakarni, A. K 2005. Indian Materia Medica. Vol-I, Popular Prakashan, Mumbai, pp-1235.

[21] Chen J.C., Chiu M.H., Nie R.L., Cordell G.A., and Qiu S.X., 2005. Cucurbitacins and cucurbitane glycosides: structures and biological activities. Nat Prod Rep 22: 386-399.

[22] Watt J M, and M. G. Breyer-Brandwijk, 1962. The Medicinal and Poisonous Plants of Southern and Eastern Africa (E. \& S. Livingston, Edinborough \& London), 2nd Ed., pp. 336-41.

[23] Fenwick G. R, C. L. Curl, N. Griffith, R. K. Heaney, K. R. Price. 1990. Bitter principles in food plants. In. Rouseff RL ed. Bitterness in food and beverages. Developments in food and science. 25:205-250. Amsterdam: Elsevier.

[24] Yang P.S., Liu Z, Cao W, Chang and Che C.T., Cucurbitacin contents in Hemsleya dolichocarpa Am. J. Chin. Med 1991. XIXX; 51-56

[25] Devendra N.K., Rajanna L and Seetharam YN. 2008, An evaluation of methods for breaking seed dormancy in $T$. $\mathrm{cu}$ cumerina L. var. cucumerina, Cucurbitaceae., My Forest. 44(3): 199-203

[26] Balbaa S.I., Zaki AY, and El-Zalabani SM. 1978. Qualitative Study of the Cucurbitacin Content in Ecballium elaterium (A. Rich) Growing In Egypt. Egypt. J. Pharm. Sci., 19:253-259

[27] Attard E., and Scicluna-Spiteri M. 2003. The cultivation and cucurbitacin content of Ecballium elaterum (L.) A. Rich. Cucurbit Genetics Cooperative Report. 26: 66-69

[28] Devendra N. Kage, Y. N. Seetharam and Vijaykumar B. Malashetty 2009. In vitro Antimicrobial activity and Phytochemical Analysis of Trichosanthes cucumerina L. var. cucumerina An important medicinal plant. Advances in Natural and Applied Sciences. 3(3); 438-441. 